\title{
Viljellyn lakan hinta on vielä korkea
}

Kalle Hoppula ${ }^{1)}$, Heli Pirinen ${ }^{2)}$ ja Markku Kajalo ${ }^{3)}$

1) MTT Sotkamo, Kipinäntie 16,88600 Sotkamo, kalle.hoppula@mtt.fi.

2) ProAgria Kainuu, Osmonkatu 9, 87100 Kajaani, heli.pirinen@proagria.fi

3) Oulun yliopisto, Kajaanin yliopistokeskus, Biotekniikan laboratorio, Salmelantie 43, 88600 Sotkamo,markku.kajalo@pp1.inet.fi

\section{Tiivistelmä}

Lakka (Rubus chamaemorus L.) on yksi Suomen arvokkaimpia luonnonmarjoja. Lakan kesyttäminen viljelykasviksi turvaa marjan saatavuutta, koska luonnossa satovaihtelua aiheuttavia riskitekijöitä pystytään viljelyssä paremmin hallitsemaan. Kainuussa toimineiden kehittämishankkeiden yhteistyönä selvitettiin talvella 2006-2007, mistä viljellyn lakan hinta muodostuu.

Lakan viljelyyn liittyvä biologinen ja viljelytekninen taustatieto kerättiin kainuulaisista erikoismarjojen viljelyn kehittämishankkeista saaduista kokemuksista, MTT Sotkamossa tehdyistä viljelykokeista sekä Norjassa Bioforsk Holt -maataloustutkimusasemalla 1970-luvulta alkaen saaduista tutkimustuloksista.

Viljellyn lakan tuotantokustannukset ovat suuret, valmiiksi poimittuna 15,10 eur/kg ja itsepoimintaan myytynäkin $7,13 \mathrm{eur} / \mathrm{kg}$. Luonnosta poimitun lakan poimijahinta on normaaleina satovuosina vaihdellut välillä 4-10 eur/kg ja ainoastaan katovuosina ollut tätä korkeampi. Lisäksi jokamiehen oikeuksin poimittujen marjojen myynnistä saatava tulo on verovapaata.

Nykytilanteessa viljellyn lakan mahdollisia markkinointi- ja myyntikanavia voisivat olla viljelyn yhdistäminen maatila- tai luontomatkailuun tai marjojen myyminen erikoistuotteena ulkomaanmarkkinoille. Toisaalta tuotantokustannuksia pitäisi saada alaspäin jalostamalla satoisampia ja suurimarjaisempia lajikkeita ja kehittämällä edelleen viljelytekniikkaa.

Asiasanat: Lakka, Rubus chamaemorus, peltoviljely, tuotantokustannukset 


\section{Johdanto}

Lakka (Rubus chamaemorus L.) on yksi Suomen arvokkaimpia luonnonmarjoja. Lakan hyödyntämistä vaikeuttavat poimijapula sekä satovaihtelut. Satovaihteluiden merkittävimpiä syitä ovat säätekijät, hede- ja emikukkien vääränlaiset määräsuhteet sekä pölytyksen epävarmuus. Lakan kesyttäminen viljelykasviksi turvaa marjan saatavuutta, koska luonnossa satovaihtelua aiheuttavia riskitekijöitä pystytään viljelyssä paremmin hallitsemaan.

Vuosina 1999-2007 toteutettujen tutkimus- ja kehittämishankkeiden seurauksena lakan viljelypinta-ala Suomessa on noussut nollasta noin 14 hehtaariin vuonna 2007. Viljely on painottunut Kainuuseen ja Pohjois-Pohjanmaalle. Viljely on edelleen erittäin epävarmaa ja sen tueksi tarvitaan lisää tietoa. Kainuussa toimineiden kehittämishankkeiden "Erikoismarjat markkinoille" (päärahoittaja Euregio Karelia / EAKR) ja "Erikoiskasvit peltoviljelyyn, jalostukseen ja markkinoille" (päärahoittaja Kainuun TE-keskus / EMOTR) yhteistyönä selvitimme talvella 2006-2007, mistä viljellyn lakan hinta muodostuu.

\section{Aineisto ja menetelmät}

Lakan viljelyyn liittyvä biologinen ja viljelytekninen taustatieto kerättiin kainuulaisista erikoismarjojen viljelyn kehittämishankkeista saaduista kokemuksista (Pirinen 2006), MTT Sotkamossa tehdyistä viljelykokeista (Hoppula ym. 2006) sekä Norjassa Bioforsk Holt -maataloustutkimusasemalla 1970luvulta alkaen saaduista tutkimustuloksista (Rapp 2005) .

Laskelmassa viljelykierron pituudeksi määrättiin 11 vuotta, joista kolmena ensimmäisenä vuotena lakka ei tuota satoa. Neljäntenä vuonna satotasoksi arvioitiin $700 \mathrm{~kg} / \mathrm{ha}$, viidentenä vuonna 950 $\mathrm{kg} / \mathrm{ha} \mathrm{ja} \mathrm{kuudennesta} \mathrm{vuodesta} \mathrm{alkaen} 1200 \mathrm{~kg} / \mathrm{ha}$.

Materiaalien ja tarvikkeiden hinnat kerättiin myyjiltä ja tässä esitetyt hinnat ovat arvonlisäverottomia. Viljelyn alussa suurin investointi on taimet, joita hehtaarin alalle tulee 40000 kappaletta. Jos hehtaarin taimet ostetaan kertaostoksena, muodostuu kappalehinnaksi 55 senttiä (hintatiedot: Peuraniemen Taimitarha).

Taimet on kätevintä istuttaa ja lannoittaa metsänistutuksesta tutulla pottiputkella $(85 \mathrm{eur} / \mathrm{kpl}$, Lännen Plant Systems Oy). Lakalle optimaalisella kasvualustalla, pehmeällä suopohjalla, traktorilla ajo onnistuu vain roudan aikana. Siksi kitkentää ja sadonkorjuuta varten laskelmissa investoitiin Elomestari Oy:n valmistamaan Ryömijään (4200 eur/kpl sis. rahtikulut).

Sotkamosta kerättyjen säätilastojen perusteella arvioitiin, että hallaa on torjuttava vuosittain keskimäärin seitsemänä yönä. Laskelmassa hallan torjuntaa varten hankitaan harsot, joiden massa on 17 g/m2 (1380 eur/ha sis. rahtikulut, Tuontiliike Ukkonen Oy) ja käyttöikä neljä vuotta. Yhdentoista vuoden viljelykierrossa tarvitaan kahdet harsot.

Palkkatasoksi sivukuluineen valittiin $12,25 \mathrm{eur} / \mathrm{h}$, viljelypinta-alaksi 1,0 ha, poimintanopeudeksi $1,9 \mathrm{~kg} / \mathrm{h}$ ja oman pääoman korkovaatimukseksi 5,0\%. Oletuksena oli, että viljelmän perustamiseen liittyvä traktorityö tehdään urakointina ja tämä urakkahinta otettiin Maatalouskalenterista 2007 (ProAgria Maaseutukeskusten Liitto 2007). Laskelmiin ei sisällytetty maataloustukia ja yleiskustannuksia.

\section{Tulokset ja tulosten tarkastelu}

Nykyisellä biologisella ja viljelyteknisellä osaamisella lakan satotasot ovat alhaisia ja viljelyn riskit suuria. Sadon hinnan muodostuminen on esitetty taulukossa 1 ja arvioidut työmenekit työvaiheittain taulukossa 2.

Viljellyn lakan tuotantokustannukset ovat suuret, valmiiksi poimittuna $15,10 \mathrm{eur} / \mathrm{kg}$ ja itsepoimintaan myytynäkin $7,13 \mathrm{eur} / \mathrm{kg}$. Luonnosta poimitun lakan poimijahinta on normaaleina satovuosina vaihdellut välillä 4-10 eur/kg ja ainoastaan katovuosina ollut tätä korkeampi. Lisäksi jokamiehen oikeuksin poimittujen marjojen myynnistä saatava tulo on verovapaata.

Lakan viljelyssä on vielä paljon kehitettävää ja tutkittavaa. Helpoimmin tuotantokustannuksia saa alas, jos satotaso nousee ja kasvustot saadaan satoikään nykyistä nuorempina. Lakan marjakokoa pitäisikin kasvattaa lajikejalostuksella ja turvaamalla pölytys sekä riittävä veden ja ravinteiden saanti. Lakka pitäisi myös saada satoikään nykyistä nuorempana esimerkiksi kehittämällä frigotaimituotantoa ja löytämällä keinoja kasvuunlähdön nopeuttamiseen. Lisäksi kukkien ja niistä kehittyvien marjojen määrää pitäisi pystyä lisäämään nykyisestä. 
Halpaa marjaa lakasta on kuitenkin vaikea saada, koska suurin yksittäinen kuluerä on poiminta, ja sen nopeuttaminen on vaikeaa. Nykytilanteessa mahdollinen markkinointitapa voisi olla esimerkiksi luonto- tai maatilamatkailun yhteydessä itsepoimijoille tarjottu "varma marjapaikka", jolloin kilohinta saataisiin luonnonlakan poimijahintojen tasalle. Suomalaisilla markkinoilla hintataso on vakiintunut tietylle tasolle. Tätä korkeampia hintoja voitaisiin saada, jos lakkaa onnistuttaisiin myymään esimerkiksi terveysvaikutuksiin tai pohjoiseen eksotiikkaan vetoavana erikoistuotteena ulkomaille.

Viljellyn lakan hinnassa päästään luonnonlakan poimijahintojen tasolle vain pahoina katovuosina, jollaisia on hintatilastojen mukaan keskimäärin kerran kymmenessä vuodessa. Tämä ei luo vielä pohjaa kannattavalle viljelylle. Luonnosta kerätyn lakan saatavuuden olennainen heikkeneminen ja siitä johtuva hinnannousu saattaisivat lisätä lakan viljelyn mielekkyyttä. Tämän varaan ei kuitenkaan vielä kannata laskea.

Taulukko 1. Lakan tuotantokustannukset euroina tuotettua lakkakiloa kohden. Laskelmassa ei ole huomioitu maataloustukien vaikutusta.

\begin{tabular}{ll}
\hline Kuluerä & eur/kg \\
\hline Taimet & 1,86 \\
Ryömijä & 0,47 \\
Harsot & 0,31 \\
Palkkakulut ilman poimintaa & 1,75 \\
Poiminta & 6,43 \\
Pakkaus ja markkinointi & 1,54 \\
Muut kulut & 1,83 \\
Oman pääoman korkovaatimus & 0,89 \\
Yhteensä & 15,10 \\
\hline
\end{tabular}

Taulukko 2. Lakan työmenekki h/ha/vuosi. Työmenekkiin ei ole laskettu viljelmän perustamiseen liittyviä urakointina teetettäviä töitä, jotka on sisällytetty tuotantokustannusten kohtaan "muut kulut".

\begin{tabular}{ll}
\hline Työvaihe & $\mathrm{h} / \mathrm{ha} /$ vuosi \\
\hline Istutus (1.vuonna) & 150 \\
Lannoitus (1. ja 6. vuonna) & 140 \\
Hallantorjunta (satovuosina) & 14 \\
Kitkentä (joka vuosi) & 30 \\
Muut työt (joka vuosi) & 60 \\
Poiminta (satotasolla $1200 \mathrm{~kg} / \mathrm{ha}$ ) & 630 \\
\hline
\end{tabular}

\section{Johtopäätökset}

Viljellyn lakan tuotantokustannukset ovat 2007 alkuvuoden hintatason mukaan valmiiksipoimittuna 15,13 euroa $/ \mathrm{kg}$ ja itsepoiminnassa 7,13 euroa $/ \mathrm{kg}$. Luonnonlakan poimijahinta on normaaleina satovuosina vaihdellut välillä 4-10 euroa/kg ja jokamiehenoikeuksin poimittu marja on poimijalle verovapaata. Siksi viljelty lakka on vielä liian kallista ns. bulkkimarjaksi.

Nykytilanteessa viljellyn lakan mahdollisia markkinointi- ja myyntikanavia voisivat olla viljelyn yhdistäminen maatila- tai luontomatkailuun tai marjojen myyminen erikoistuotteena ulkomaanmarkkinoille. Toisaalta hintaa pitäisi saada alaspäin jalostamalla satoisampia ja suurimarjaisempia lajikkeita ja kehittämällä edelleen viljelytekniikkaa. 


\section{Kirjallisuus}

Hoppula, K., Pirinen, H., Miettinen, M. 2006. Lakasta viljelykasvi?. In: Toim. Anneli Hopponen. Maataloustieteen Päivät 2006, 11.-12.1.2006 Viikki, Helsinki [: esitelmät ja posterit]. Suomen maataloustieteellisen seuran tiedote 21: 6 s. http://www.smts.fi/pos06/0107.pdf

ProAgria Maaseutukeskusten Liitto. 2007. Maatalouskalenteri 2007. ProAgria Maaseutukeskusten Liitto, Vantaa. 244 s.

Pirinen, H. 2006. Lakan viljelyopas. ProAgria Kainuu, Kajaani. 19 s.

Rapp, K. 2005. Cloudberry growers guide. The Norwegian Crop Research Institute, Holt Research Station, Tromsø, Norway. 16 pp. 